\title{
The Concentrations of Nitrate in Pasture Grasses, Legumes, Soiling Crops and Silage Practically Used in Japan
}

\author{
Akira Miyazaki, Shoji Uesaka and Eizo Tsuda \\ (College of Agriculture, Kyoto University) \\ (Received for publication on August 8, 1966)
}

It has long been known in the field of plant physiology that nitrate taken up by a cell as the anion $\mathrm{NO}_{3}{ }^{-}$is partly reduced and assimilated to amino acids and protein. However, when the intake of nitrate by the plants exceeds the consumption, nitrate is accumulated in large amounts in the plants.

When cattle or sheep are fed with the forage containing much nitrate, there is a danger of nitrate poisoning ${ }^{2)}$. Even if the concentrations of nitrate were not so large as to be lethal to the animals, the economic performance of the ruminants would be reduced. That is, the high concentrations of nitrate in the feed seem to cause an abortion ${ }^{8)}$, loss in body weight gains ${ }^{29}$ ) and decrease in milk production ${ }^{7)}$ of the ruminants. Therefore, it is important for a stockman to have an accurate knowledge on the concentrations of nitrate in forage crops in his field.

The levels of nitrate in the feed that are toxic to animals are hard to be defined, because the response of nitrate upon the animals is remarkably affected by the dietary factors such as the contents of protein and carbohydrate in the feed they are fed with. However, in 1940, BRADLEY et al. ${ }^{1}$ ) set arbitrarily 1.5 per cent potassium nitrate in air-dry matter as the dividing line between toxic and non-toxic feeds. Though this figure cannot be regarded as a completely established one, it has been remarked threafter that the forage crops containing nitrate more than 1.5 per cent as potassium nitrate in air-dry matter are dangerous. It has been reported in U.S.A.8,14,21,81) that cultivated plants or weeds such as oats, corn, sorghum, pigweed, thistle, bluepanicgrass etc. occassionally contain nitrate more than the toxic level. Similar results have been reported in Canada ${ }^{5)}$, Australia ${ }^{28)}$, Germany ${ }^{1)}$, New Zealand ${ }^{12)}$ and some other countries $^{11,221}$. In these countries, several workers have been warning the practical farmers against using high-nitrate roughage at the time of feeding and pasturing.

However, since we have no trace of the apparent nitrate poisoning of cattle or sheep in the field in Japan, there are few reports on the concentrations of nitrate in forage crops. Recently, the application of nitrogen fertilizer or weed killer came to be not so uncommon in the field in Japan and they were known to accumulate nitrate in plants. Therefore, it is important to know outline of the concentrations of nitrate in forage crops in Japan. The investigations reported in this paper were undertaken to present the approximate informations on the concentrations of nitrate in cultivated grasses, legumes, soiling crops and silage practically used in Japan.

\section{Methods and Materials}

Samples of various grasses and legumes were obtained from the fields of twenty-eight 


\section{MiYazaKI - Uesaka - Tsuda}

Agricultural Experiment Stations. These stations were located at Hokkaido, Akita, Iwate, Niigata, Ibaragi, Tochigi, Chiba, Gifu, Mie, Shiga, Nara, Kyoto, Osaka, Wakayama, Hyogo, Shimane, Hiroshima, Tottori, Kagawa, Kochi and Kumamoto prefectures. The number of samples was one hundred and sixty-four. The detail of them was as follows:

$\begin{array}{llrlr}\text { grasses } & \text { Italian ryegrass } & 28 & \text { Kentucky 31 fescue } & 8 \\ & \text { orchard grass } & 27 & \text { other thirteen species } & 26 \\ \text { legumes } & \text { Ladino clover } & 28 & \text { alfalfa } & 10 \\ & \text { red clover } & 27 & \text { other six species } & 7 \\ \text { others } & \text { mixed grass } & 2 & \text { Russian comfrey } & 1\end{array}$

They were cut approximately at the adequate stages for feeding, that is, at the heading stage for grasses and at the flowering stage for legumes in Spring in 1964 and 1965 . They were rapidly dried and were sent to Kyoto University. The soil conditions and the treatments such as the amounts of fertilizer applied to every grasses and legumes were different each other. However, they were not special samples but were the plants generally used for feeding in practical farms. Besides, samples of soiling crops and silage were collected from the fields of Kyoto Farm and Takahara Livestock Experiment Station of Kyoto University and from the fields on the outskirts of them in 1963, 1964 and 1965. It was because samples of soiling crops and silage were bulky and could not be obtained from various districts. The number of samples was seventy-seven. The detail of them was as follows:

$\begin{array}{lrlr}\text { oats } & 30 & \text { soybean } & 5 \\ \text { corn } & 10 & \text { turnip } & 10 \\ \text { rye } & 7 & \text { silage } & 15\end{array}$

They were not cut equally at the same stages of development as in the cases of grasses and legumes, but they were large enough to be generally used for feeding animals. At the time of sampling, the amounts of fertilizer applied to these plants were approximately checked up. Nitrate in these samples was determined by the colorimetric method by MorRis et al. ${ }^{19 l}$ and was expressed in percent of potassium nitrate equivalent in dry matter.

\section{Results and Discussions}

An outline of the concentrations of nitrate in grasses and legumes in various districts in Japan is shown in figure 1 .

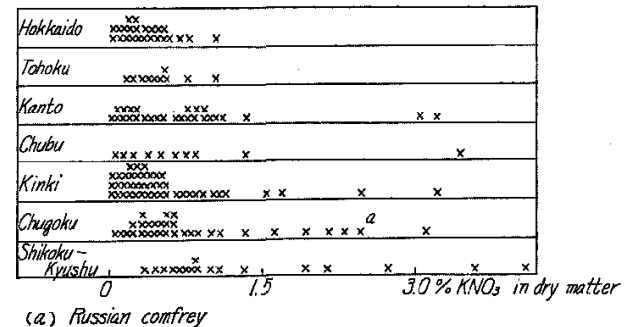

Hokkaido : Hokkaido 24

$\begin{array}{llrlrlr}\text { Tohoku } & \text { : Akita } & 5 & \text { Iwate } & 5 & & \\ \text { Kanto } & \text { Ibaragi } & 8 & \text { Tochigi } & 6 & \text { Chiba } & 13 \\ \text { Chubu } & \text { : Niigata } & 4 & \text { Gifu } & 6 & & \\ \text { Kinki } & \text { : Mie } & 6 & \text { Shiga } & 6 & \text { Nara } & 5 \\ & \text { Osaka } & 9 & \text { Wakayama } & 6 & \text { Hyogo } & 8 \\ \text { Chugoku } & \text { : Tottori } & 9 & \text { Shimane } & 11 & \text { Hiroshima } & 12 \\ \begin{array}{c}\text { Shikoku- } \\ \text { Kyushu }\end{array} & \text { : Kagawa } & 6 & \text { Kochi } & 6 & \text { Kumamoto } & 5\end{array}$

Fig. 1. The concentrations of nitrate in grasses and legumes in various districts in Japan 
Nitrate in roughage used in Japan

Though samples were not sufficient in amount and not even in each district, the approximate informations on the concentrations of nitrate in pasture grasses and legumes in Japan were obtained. The concentrations seemed to range widely and could not be defined exactly in every direction. In almost all the districts, except in Hokkaido and Tohoku districts, there were several samples containing nitrate exceptionally high. Such plants would result in severe loss of the animals, if they were full-fed in feeding. However, the concentrations in the greater part of pasture grasses and legumes in Japan were less than 1.5 per cent as potassium nitrate in dry matter. In other words, the concentrations of nitrate in only 11 per cent of total samples analysed were more than 1.5 per cent. However, it was remarked that 4 per cent out of the 11 per cent of the samples contained nitrate more than 3 per cent, which was fairly higher than toxic concentration reported by the earlier workers ${ }^{2)}$. Such a high concentration was generally found in the samples of grasses. The reason why there has been no trace of apparent nitrate poisoning in Japan seems to be that cattle or sheep are scarcely full-fed with roughage only.

In order to get the approximate informations on the concentrations of nitrate in Japan, the concentrations in figure 1 were classified into two regional groups, i.e., the northeastern part and the southwestern part of Japan, by setting up the borderline between Kinki and Chugoku districts, and it was found that the concentrations of nitrate in plants in the southwestern part were fairly higher than those in the northeastern part. In the northeastern part, about 90 per cent of the samples contained nitrate less than 1.0 per cent as potassium nitrate in dry matter. On the other hand, in the southwestern part, about 30 per cent of the samples containd nitrate more than 1.0 per cent. Among them, the concentrations in the samples in Shikoku-Kyushu district seemed to be high. The reason was not apparent, but authors supposed that, under comparatively high temperature, plants would absorb much nitrate from the soil. It seemed in this experiment that the concentrations of nitrate in pasture grasses and legumes cut at the adequate stages for feeding were generally not so high as to be expected.

The concentrations of nitrate in grasses and legumes are shown respectively in table 1. In this table, average concentrations and standard deviation were calculated, excluding several exceptional concentrations. As a matter of course, three miscellaneous samples (mixed grass and Russian comfrey) were excluded.

Table 1. The concentrations of nitrate in grasses and legumes in Japana)

\begin{tabular}{l|c|c|c|c}
\hline & $\begin{array}{c}\text { No. of } \\
\text { samples }\end{array}$ & $\begin{array}{c}\text { Range of the concen- } \\
\text { trations of nitrate }\end{array}$ & $\begin{array}{c}\text { Samples containing } \\
\text { nitrate more than 1.5\% }\end{array}$ & Av. \pm s.d. \\
\hline Grasses & 89 & $0.02-4.11 \%$ & 11 & $0.36 \pm 0.27 \%$ \\
Legumes & 72 & $0.18-3.60$ & 6 & $0.61 \pm 0.27$ \\
Total & 161 & $0.02-4.11$ & 17 & $0.48 \pm 0.30$ \\
\hline
\end{tabular}

a) Percent potassium nitrate in dry matter.

The concentrations of nitrate in grasses ranged from 0.02 to 4.11 per cent as potassium nitrate in dry matter. But the concentrations in seventy-eight samples out of eighty-nine were not more than 1.30 per cent. The concentrations of nitrate in legumes ranged from 0.18 to 3.60 per cent. In legumes, there were a few samples containing nitrate more than 2.0 per cent. However, the concentrations in the greater part of the samples were not more 


\section{MiYazakI - Uesaka - Tsuda}

than 1.30 per cent, as in the case of grasses. In this experiment, the samples containing exceptionally much nitrate were apparently less in legumes. It has been known in the field of plant physiology that among the sources of nitrogen absorbed by legurnes, the most important one is nitrogen synthesized by nodule bacteria. Since it is in forms of asparatic acid and glutamic acid ${ }^{15)}$ that legumes are supplied by the bacteria with nitrogen, it has been mentioned that legumes generally do not accumulate much nitrate. The results obtained in the experiment seemed to be reasonable in this point. The average concentrations of nitrate in cultivated grasses and legumes, excluding some exceptional concentrations, were $0.36 \pm 0.27$ per cent for grasses and $0.61 \pm 0.27$ per cent for legumes. It was remarked that the average concentration in legumes seemed to be more than that in grasses cut at the adequate stage for feeding. The results were in general agreement with those obtained in the previous investigations ${ }^{27)}$ which were undertaken to compare the accumulation of nitrate in grasses and legumes at species level. From the results of this experiment, except some exceptional concentrations, the concentrations of nitrate in pasture grasses and legumes in Japan seemed to be not so much. Since feeding roughage with high nitrate concentration is known to be harmful to the animals ${ }^{2)}$, it is important for a stockman to know where the exceptionallyhigh-nitrate-containing grasses and legumes were produced. The results are shown in table 2.

Table 2. The concentrations of nitrate in exceptionally-high-nitrate-containing grasses and legumesa)

\begin{tabular}{|c|c|c|c|c|}
\hline \multirow{2}{*}{$\begin{array}{c}\text { Sample cultivated } \\
\text { in }\end{array}$} & \multicolumn{2}{|c|}{ Grasses } & \multicolumn{2}{|c|}{ Legumes } \\
\hline & species & concentration & species & concentration \\
\hline Ibaragi pref. & Italian ryegrass & $3.12 \%$ & & \\
\hline "I & $\prime \prime$ & 3.26 & & \\
\hline Niigata & $\prime \prime$ & 3.40 & & \\
\hline Mie & "1 & 3.24 & & \\
\hline Shiga & $\prime \prime$ & 1.57 & & \\
\hline Hyogo & Orchard grass & 2.64 & & \\
\hline Wakayama & & & Ladino clover & $1.78 \%$ \\
\hline Shimane & Italian ryegrass & 3.19 & & \\
\hline Hiroshima & $\prime \prime$ & 2.23 & Alfalfa & 1.97 \\
\hline$\prime \prime$ & $\prime \prime$ & 2.38 & Ladino clover & 1.66 \\
\hline Kagawa & $\prime \prime$ & 1.90 & $\prime \prime$ & 3.60 \\
\hline Kochi & & & $\prime \prime$ & 2.16 \\
\hline Kumamoto & Kentucky 31 fescue & 4.11 & $\prime \prime$ & 2.72 \\
\hline
\end{tabular}

a) Percent potassium nitrate in dry matter.

The exceptionally-high-nitrate-containing plants were found mainly in the southwestern part in Japan. The leading species of them were Italian ryegrass in grasses and Ladino clover in legumes. In grasses, though the highest concentration was found in Kentucky 31 fescue, the highest concentration of nitrate was mainly found in the samples of Italian ryegrass. It was remarked in this experiment that there were large individual differences among the concentrations of nitrate in samples produced in the same experiment station. For example, the concentrations in Italian ryegrass in Ibaragi Experiment Station were about 3 per cent in two samples and less than 1 per cent in four samples. Such a "spottiness", 
one of the characteristics of nitrate accumulation in plants, was already reported by several workers ${ }^{14,16,21,25)}$.

It has been known that high concentrations of nitrate in plants are associated with drought $t^{5,6,10)}$, nitrogen fertilization ${ }^{4,9,32)}$, soil fertility ${ }^{8)}$ and herbicide treatment ${ }^{24,80)}$. In this experiment, though authors failed to have enough informations on the field conditions of each experiment station, the exceptionally high concentrations of nitrate in the plants seemed to be not necessarily associated with high application of nitrogen fertilizer. It was also remarked that there were some experiment stations where exceptionally-high-nitrate-containing plants were produced. Those were Nanatsukahara Livestock Farm and Yuki Livestock Farm in Hiroshima prefecture, Zootechnical Experiment Station in Kagawa prefecture and Kyushu National Agricultural Experiment Station in Kumamoto prefecture. These stations were established earlier and the field of them seemed to be fertile. The authors supposed that high concentrations of nitrate seemed to be related to soil fertility. In legumes, Ladino clover seemed to contain more nitrate than the other species. However, the concentrations were not so much as in grasses and even if they were considerably high, legumes would not result in severe loss of the animals because full-feeding with legumes were not prevalent in feeding. It was due to the fact that bloat associated with full-feeding with legumes was known to be more dangerous than nitrate poisoning in animal production in Japan. Therefore, it seemed to be nitrate in grasses, not in legumes, that should be paid attention to in animal feeding. Especially, since grasses seemed to contain two or three times as much nitrate at the early stages of development as those at the heading stage, it was estimated that the concentrations of nitrate in such exceptional samples were very high at the early stages of development and perhaps such grasses would be very dangerous.

The concentrations of nitrate in leading species of grasses and legumes in Japan are summarized in table 3 .

Table 3. The concentrations of nitrate in leading species of grasses and legumesa)

\begin{tabular}{l|c|c|c|c}
\hline & $\begin{array}{c}\text { No. of } \\
\text { samples }\end{array}$ & $\begin{array}{c}\text { Range of the concen- } \\
\text { trations of nitrate }\end{array}$ & $\begin{array}{c}\text { Samples containing } \\
\text { nitrate more than 1.5\% }\end{array}$ & Av.+ s.d. \\
\hline Grasses & & $\%$ & & $\%$ \\
Italian ryegrass & 28 & $0.06-3.40$ & 1 & $0.33 \pm 0.21$ \\
Orchard grass & 27 & $0.07-2.63$ & 1 & $0.37 \pm 0.29$ \\
Kentucky 31 F. & 8 & $0.14-4.11$ & & $0.45 \pm 0.26$ \\
Legumes & & & 5 & \\
Ladino clover & 28 & $0.26-3.60$ & 0 & $0.77 \pm 0.30$ \\
Red clover & 27 & $0.22-1.11$ & 1 & $0.61 \pm 0.21$ \\
Alfalfa & 10 & $0.18-1.97$ & & 1 \\
\hline
\end{tabular}

a) Percent potassium nitrate in dry matter.

Except some exceptional concentrations (already shown in table 2), those in Italian ryegrass were considerably low and were $0.33 \pm 0.21$ per cent. The concentrations were a little less than those in orchard grass ( $0.37 \pm 0.29$ per cent) and Kentucky 31 fescue (0.45 \pm 0.26 per cent). However, under some unfavorable conditions, Italian ryegrass seemed to contain more nitrate than the other grasses. In such a case, the concentrations would be frequently over 3 per cent. That is, the concentrations of nitrate in Italian ryegrass at the heading 
stage seemed to be divided roughly into two groups. The reason was not apparent, but, selecting non-nitrate-accumulating species, it was important to know the peculiarity of accumulation of nitrate in each plant. KRETSCHMER ${ }^{17)}$ reported that the concentrations of nitrate in Italian ryegrass were considerably high, but UESAra et al. ${ }^{27)}$ reported that those were considerably low. These data seemed to be inconsistent with each other. Authors supposed that the difference was due to such a peculiarity of accumulation of nitrate in Italian ryegrass. Among three leading species of legumes, the concentrations of nitrate in Ladino clover were considerably high and were $0.77 \pm 0.30$ per cent with some exceptions. Those in red clover were, with no exception, low and were $0.51 \pm 0.21$ per cent. Those in alfalfa were $0.61 \pm 0.22$ per cent. The results are in general agreement with the data reported previously ${ }^{28,26)}$.

The concentrations of nitrate in other miscellaneous grasses and legumes are shown in table 4.

Table 4. The concentrations of nitrate in miscellaneous grasses and legumesa)

\begin{tabular}{l|c|c}
\hline & $\begin{array}{l}\text { No. of } \\
\text { samples }\end{array}$ & the concentrations of nitrate \\
\hline Grasses & 5 & $0.14,0.19,0.23,0.28,0,35 \%$ \\
Timothy & 3 & $0.27,0.31,0.57$ \\
Tall fescue & 3 & $0.20,0.27,0.28$ \\
Meadow fescue & 3 & $0.17,0.18,0.44$ \\
Tall oat grass & 2 & $0.07,0.18$ \\
Red top & 2 & $0.19,0.24$ \\
Perennial ryegrass & 2 & $0.18,0.60$ \\
H 1 ryegrass & & $0.60,0.61$ \\
Legumes & 2 & \\
Alsike clover & & \\
\hline
\end{tabular}

a) Percent potassium nitrate in dry matter.

The concentrations of nitrate in these grasses were considerably low and mainly less than 0.36 per cent (the average concentration in grasses shown in table 1). Those in Alsike clover were almost equal to the average concentration in legumes.

The samples of other grasses and legumes contained various concentrations of nitrate. The concentrations in grasses were : reed canary grass, $1.27 \%$, Bahia-grass, $0.65 \%$, creeping red fescue, $0.29 \%$, bromegrass, $1.21 \%$, weeping lovegrass, $0.02 \%$ and rescue grass, $0.76 \%$. Those in legumes were: sweet clover, $0.63 \%$, crimson clover, $0.34 \%$, vetch, $0.34 \%$, Egyptian clover, $0.26 \%$ and milk vetch, $0.29 \%$. Of these plants analysed, reed canary grass and bromegrass seemed to contain much nitrate. In this experiment, authors could not find that grasses, having the growth habits similar to oat and ryegrass, contained large amounts of nitrate as reported by $\mathrm{KRETSCHMER}^{17)}$. However, it is interesting to know the relationships between the concentrations of nitrate and plant habits.

The concentrations of nitrate in soiling crops and silage in Kyoto are shown in table 5 .

As was known by the name of oat hay poisoning, oats seemed to accumulate much nitrate. The concentrations of nitrate in solling oats generally used for feeding ranged from 0.27 to 2.52 per cent, averaging $1.29 \pm 0.56$ per cent. The average concentration in oats was apparently larger than those in grasses and legumes. At the time of sampling grasses and legumes in this 
Nitrate in roughage used in Japan

Table 5. The concentrations of nitrate in soiling plants and silagea)

\begin{tabular}{l|c|c|c}
\hline & $\begin{array}{c}\text { No. of } \\
\text { samples }\end{array}$ & $\begin{array}{c}\text { Range of the concen- } \\
\text { trations of nitrate }\end{array}$ & Av.ts.d. \\
\hline Soiling plants & & $0.27-2.52 \%$ & $1.29 \pm 0.56 \%$ \\
Oat & 30 & $0.60-1.41$ & $0.95 \pm 0.24$ \\
Corn & 10 & $0.11-2.03$ & $0.98 \pm 0.61$ \\
Rye & 7 & $0.33-0.87$ & $0.53 \pm 0.21$ \\
Soybean & 5 & $0.01-2.74$ & $0.90 \pm 0.87$ \\
Turnip & 10 & $0.09-0.60$ & $0.32 \pm 0.14$ \\
Silageb) & 15 & &
\end{tabular}

a) Percent potassium nitrate in dry matter.

b) Ensiled plants : milk vetch, 7 oat, 5 others, 3 .

experiment, four samples of soiling oats were sent from some experiment stations. The concentrations of nitrate in these oats were as follows: Shiga prefecture; $0.17 \%$, Shimane prefecture; $2.21 \%$ (Izumo), $1.04 \%$ and $0.25 \%$ (Ota) as potassium nitrate in dry matter. These concentrations were not so different, comparing with those shown in table 5 . Kato et $a l{ }^{13)}$ reported that the concentration of nitrate in oat grown in the ordinary field in Kanagawa prefecture was 1.19 per cent. The figure was almost equal to the average concentration of nitrate in soiling oats in this experiment. Therefore, though the concentrations of nitrate in soiling oats in table 5 were obtained from only one prefecture (Kyoto) and could not be considered as typical concentrations of nitrate in soiling oats cultivated in Japan, authors supposed that the concentrations in this experiment seemed to be not so exceptional ones. However, it was reported ${ }^{26)}$ that the concentrations of nitrate in oats were prominent at the early stages of development and they decreased as the growing stages progressed. If oats were cut a little earlier, the concentrations would exceed toxic level set by the earlier workers $^{23}$. Many farmers in Japan cannot have enough hay and silage at the end of wintering and cattle cannot help ingesting very young plants in early spring. In such a case, young oats is one of the most commonly-used plants. However, no apparent nitrate poisoning was reported in Japan. Authors supposed that young oats were not full-fed to cattle by experienced stockman because unaccountable diarrhea was frequently accompanied with feeding young oats.

The concentrations of nitrate in soiling corn ranged from 0.60 to 1.41 per cent, averaging 0.95 per cent. It seemed in this experiment that soiling corn accumulated less nitrate than soiling oats. However, it was apparent by the name of corn stalk disease ${ }^{18)}$ that corn sometimes seemed to contain considerably high nitrate and such a corn would result in severe loss of the animals. High-nitrate-containing samples seemed to be found in young corn as was shown in oats ${ }^{26)}$.

Those in soiling rye ranged from 0.41 to 2.03 per cent as were equal to those in soiling oats, but the average concentration was considerably low. It was apparent in this experiment that the concentrations of nitrate in soiling cereal plants cut at the adequate stage were not so much in every plants. However, in these soiling plants, it was well-known that the concentrations of nitrate were fairly high at the early stages of development. Therefore, it was persuaded that soiling cereal plants should not be cut too young for feeding.

The concentrations of nitrate in soiling soybean were considerably low as expected and 


\section{MiYazakI - Uesaka - Tsuda}

ranged from 0.33 to 0.87 per cent, averaging 0.53 per cent. They were in general agreement with those reported by GiLBERT et al. ${ }^{81}$.

Those in turnip were variable and ranged from 0.01 to 2.74 per cent. The latter figure was the highest concentration in the samples of soiling crops cut at the adequate stage for feeding. It was apparent that turnip was one of the most nitrate-containing plants. The result was in general agreement with that reported by BuYSEE ${ }^{3)}$. "Spottiness" in the concentrations of nitrate seemed to be prominent in this plant. Therefore, it is important to know the factors affecting the concentrations of nitrate in root crops. 2,4-D is one of the factors reported by the earlier workers ${ }^{21,30)}$.

The concentrations of nitrate in silage seemed to be considerably low as was indicated by MUHRER ${ }^{20)}$. It was well-known that ensiling might result in the formation of various nitrogen oxides in gaseous form. Such gases seemed to be mainly formed from the nitrate in plant material during fermentation. Though the concentrations in plants before ensiling could not be determined, it was supposed that nitrate in plants decreased during fermentation periods and ensiling might reduce nitrate in plants from toxic to non-toxic.

\section{Summary}

1) The concentrations of nitrate in grasses, legumes, soiling crops and silage were determined to get the approximate informations on the concentrations of nitrate in roughage practically used in Japan.

2) Samples of various grasses and legumes were obtained from the fields of twenty-eight Agricultural Experiment Stations. These stations were located at Hokkaido, Akita, Iwate, Niigata, Ibaragi, Tochigi, Chiba, Gifu, Mie, Shiga, Nara, Kyoto, Osaka, Wakayama, Hyogo, Shimane, Hiroshima, Tottori, Kagawa, Kochi and Kumamoto prefectures. The samples of soiling crops and silage were collected from the fields of two experimental farms of Kyoto University and from the fields on the outskirts of them. The number of the samples was one hundred and sixty-four for grasses and legumes and seventy-seven for soiling crops and silage.

3) The concentrations of nitrate in grasses ranged from 0.02 to 4.11 per cent as potassium nitrate in dry matter and those in legumes ranged from 0.18 to 3.60 per cent. The average concentrations of nitrate in cultivated grasses and legumes, excluding some exceptional concentrations, were $0.36 \pm 0.27$ per cent for grasses and $0.61 \pm 0.27$ per cent for legumes. The concentrations of nitrate in grasses seemed to be less than those in legumes. There were several samples containing nitrate exceptionally high and those samples were apparently more in grasses, and the leading species of them were Italian ryegrass in grasses and Ladino clover in legumes.

4) Except some exceptional concentrations, the concentrations of nitrate in Italian ryegrass were $0.33 \pm 0.21$ per cent as potassium nitrate in dry matter. Those in orchard grass and Kentucky 31 fescue were $0.37 \pm 0.29$ and $0.45 \pm 0.26$ per cent. Those in Ladino clover seemed to be high and were $0.77 \pm 0.30$ per cent except some exceptional ones. Those in red clover were $0.51 \pm 0.21$ per cent with no exception.

5) According to the results of this research, the concentrations of nitrate in plants in the southwestern part (Chugoku, Shikoku and Kyushu districts) seemed to be fairly higher than those in the northeastern part (Hokkaido, Tohoku, Kanto, Chubu and Kinki districts). It was also remarked that there were some experiment stations where exceptionally-high- 
nitrate-containing plants were produced. These stations were located at Hiroshima, Kagawa. and Kumamoto prefectures.

6) The concentrations of nitrate in soiling crops were considerably higher than those in grasses and legumes. Those in soiling oats generally used for feeding ranged from 0.27 to 2.52 per cent, averaging $1.29 \pm 0.56$ per cent. Those in soiling corn ranged from 0.60 to 1.41 per cent, averaging 0.95 per cent. In this experiment, soiling soybean seemed to contain less. nitrate. The concentrations of nitrate in turnip were variable and it seemed that turnip was. one of the most nitrate-accumulating plants. Those in silage were considerably low and were less than 0.60 per cent.

\section{Acknowledgment}

The authors are grateful to the staffs of these twenty-eight Agricultural Experiment Stations for supplying samples of various grasses and legumes. They are also grateful to Dr. Ryoji KAWASHIMA for his interest in this work.

\section{References}

1) Becker, M. and W. Oslage (1955) Landwirtsch. Forsh., 8: 100-110.

2) Bradley, W.B., H.F. Eppson and O.A. Beath (1940) Wyo. Agric. Exp. Sta. Bull., 241.

3) Buysee, F. (1956) Med. Landb. Hogenschool Gent., 21 : 59-65.

4) Crawford, R.F., W.K. Kennedy and W.C. Johnson (1961) Agron. J., $53: 159$-162.

5) Doughty, J.L. and F.G. WArder (1942) Sci. Agric., $23: 233-236$.

6) Flynn, L.M., C.W. Gehrke, M.E. Muhrer, G.S. Smith and M.S. Zuber (1957) Mo. Agric. Exp. Sta. Res. Bull., 620.

7) Garner, G.B. (1958) Mo. Agric. Exp. Sta. Bull., 708.

8) Gilbert, C.S., H.F. Eppson, W.B. Bradley and O.A. Beath (1946) Wyo. Agric. Exp. Sta. Bull., 277.

9) Griffith, G. aP (1960) Nature, $185: 627-628$.

10) Hanway, J.J. and A.J. Englehorn (1958) Agron. J., $50: 331-334$.

11) Harker, K.W. and A.K. Kamau (1961) East African Agric. Forest. J., $27: 57-60$.

12) Jamieson, N.D. (1959) N.Z.J. Agric. Res., 2 : 96-106.

13) Kato, S. and E. Kosuge (1964) Kanagawa Zootech. Exp. Sta. Bull., 39-7 : 11-14.

14) Kendrick, J.W., J. Tucher and S.A. Peoples (1955) J. Amer. Vet. Med. Ass., $126: 53-56$.

15) Kitagrshi, K. (1964) Proc. 10 th. Aniversary Symposium Jap. Soc. Grassland Sci., 74-77.

16) Krantz, B.A., W.L. Nelson and L.F. Burkhart (1948) Diagnostic Techniques for Soils and Crops, 137-155. Amer. Potash Inst. Wash. D.C.

17) Kretschmer, Jr., A.E. (1958) Agron. J., $50: 314-316$.

18) MaYo, N.S. (1896) Kansas Agric. Exp. Sta. Bull., $58: 65-88$.

19) Morris, M.P. and Alma González-Más (1958) Agric. Food Chem., 6:456-457.

20) Muhrer, M.E. (1955) Mo. Agric. Exp. Sta. Bull., 652: 19-20.

21) Olson, O.E. and E. Whitehead (1941) Proc. S.D. Acad. Sci., 20:95-101.

22) O'MOore, L.B. (1955) Irish Vet. J., $9: 292-293$.

23) Perez, JR., C.B. and C.D. Story (1960) J. Anim. Sci., $19: 1311$.

24) Stanler, L.M. and E.I. Whitehead (1950) Science, $112: 749-751$. 


\section{MiYazaki - Uesaka - Tsuda}

25) Tucker, J.M., D.R. Cordy, L.J. Berry, W.A. Harvey and T.C. Fuller (1961) Calif. Agric. Exp. Sta. Extention Service Circular, 506.

26) Uesaka, S. and A. Miyazaki (1963) J. Jap. Soc. Grassland Sci., 9:41-47.

27) Uesaka, S. and A. Mryazaki (1965) Jap. J. Zootech. Sci., $36: 81-85$.

28) Webв, L.J. (1952) J. Aust. Inst. Agric. Sci., 18: 164-167.

29) Weichenthal, B.A., L.B. Embry, R.J. Emerick and F.W. Whetzal (1963) J. Anim. Sci., $22: 979-984$.

30) Whitehead, E.I., J. Kersten and D. Jacobsen (1956) Proc. S.D. Acad. Sci., $35: 106-110$.

31) WiLson, J.K. (1949) Agron. J., $41: 20-22$.

32) Wright, N., R.J. Trautman and L. J. Streetman (1960) Agron. J., 52:671-672.

本邦産牧草, 青刚飼料作物, サイレージの硝酸塩含量について

宮崎昭・上坂章次・津田栄三 (京都大学農学 部)

本邦でふつうに载培され家畜に給与されている牧草, 青刈飼料作物，サイレージにどの程度の硝酸塩ぶ含まれ ているが知るために, 各地の畜産試験場, 種蓄場など から牧草を入手しその硝酸塩定量した。 それらの場所 数は28であり, 地域別にみると北海道, 秋田, 岩手, 新渴, 茨城, 杤木, 千葉, 岐阜, 三重, 滋賀, 奈良, 京 都，大阪，和歌山，兵庫，島根，広島，鳥取，香川，高 知, 熊本の各府県であつた. 分析点数恔牧草について イネ科，マメ科あわせて 164 点であつた。また青刈飼料 作物，サイレージは各地から入手することが困難であつ たので主として京都近郊加らこれ劣入手した。これらの 試料はすべてふつう家畜に給与している程度にまで生育 したものであり，とくにイネ科牧草では出穂期，マメ科 牧草では開花期に刚取つたものであつた.イネ科牧草の 硝酸塭含量は乾物中 $\mathrm{KNO}_{3}$ として $0.02 \sim 4.11 \%$, マメ 科牧草のそれは $0.18 〜 3.60 \%$ であつた。しかし全試料 の $89 \%$ のものでは，その确酸塩含量以乾物中 $\mathrm{KNO}_{3}$ と して $1.5 \%$ 以下であつた. したがつて本邦でふつうに用 いられている牧草の硝酸塩含量は全般的にはかなり少な いものと推察される.しかし残りの $11 \%$ のあの硝酸 塩含量は変異が広く，なかに汇 $3 \%$ を越すものも如 た、このように多くの硝酸塩を含む試料は，マメ科より イネ科のものに多く，またとの草種こしてはイネ科では イタリフンライグラス, マメ科ではラジノクローバーが
主なものであつた。本試験では硝酸塩安乾物中 $\mathrm{KNO}_{3}$ と して $1.5 \%$ 以上合む牧草は全体の 1 割程度であつたの でこのようなるの定まとめて平均すれば，その平均值 は全体の様相必ずしも反胦しないきらいがある。そこ でこれら除外して作に平均值求めると，イネ科で は $0.36 \pm 0.27 \%$ ，マメ科では $0.61 \pm 0.27 \%$ であつた。 つぎに個々のものについてみると，イタリアンライグラ ス, $0.33 \pm 0.21 \%$ ，オーチャードグラス, $0.37 \pm 0.29 \%$, ケンタッキー 31 フエスク， $0.45 \pm 0.26 \%$ ，ラジノクロ ーパー， $0.77 \pm 0.30 \%$ であつた. レッドクローバーで は27点を分析したが，1.5\% 以上の硝酸塩念むるのは なく, 平均 $0.51 \pm 0.21 \%$ となつていた. な执タリア ンライグラスでは大抵の場合硝酸塩含量は少ないが，と きに渄常に多いこともあり注目された：これら牧草の 硝酸塩含量は地域别飞みると，兵席県以西放呫手した ものにとくに多いようであり，広島，香川，熊本の各県 ではとくに硝酸湓含量が多い牧草がみうけられた．青肧 飼料作物ではェンバク $1.29 \pm 0.56 \%$ ，トウモロコシ0.95 士0.24\%，ライムギ $0.98 \pm 0.61 \%$ で㘯つた. 飼料カブ ではその含量の変買が大きく，0.01〜2.74\% となつて いた．青刚大豆やサイレージではその硝酸塩含量は全般 にかなり少なく，乾物中 $\mathrm{KNO}_{3}$ として $0.5 \%$ 前後であ つた. 